\title{
PENGARUH MODEL PBL BERMUATAN KEARIFAN LOKAL TERHADAP SIKAP SOSIAL DAN KEMAMPUAN BERPIKIR KRITIS MATEMATIKA SISWA KELAS V DI GUGUS V KECAMATAN SUKASADA
}

\author{
Putu Era Primayanti \\ Program Studi Pendidikan Guru Sekolah Dasar, Universitas Pendidikan Ganesha \\ Email: eraprimayanti19@gmail.com \\ I Made Suarjana \\ Program Studi Pendidikan Guru Sekolah Dasar, Universitas Pendidikan Ganesha \\ Email: imade.suarjana@undiksha.ac.id \\ I Gede Astawan \\ Program Studi Pendidikan Guru Sekolah Dasar, Universitas Pendidikan Ganesha \\ Email: igedeastawan@undiksha.ac.id
}

\begin{abstract}
Abstrak
Penelitian ini bertujuan untuk mengetahui 1) perbedaan secara simultan sikap sosial dan kemampuan berpikir kritis matematika antara kelompok siswa yang mengikuti model PBL bermuatan kearifan lokal dan kelompok siswa yang mengikuti pembelajaran konvensional pada siswa kelas V di Gugus V Kecamatan Sukasada. 2) perbedaan sikap sosial antara kelompok siswa yang mengikuti model PBL bermuatan kearifan lokal dan kelompok siswa yang mengikuti pembelajaran konvensional pada siswa kelas V di Gugus V Kecamatan Sukasada. 3) perbedaan kemampuan berpikir kritis matematika antara kelompok siswa yang mengikuti model PBL bermuatan kearifan lokal dan kelompok siswa yang mengikuti pembelajaran konvensional pada siswa kelas V di Gugus V Kecamatan Sukasada. Jenis penelitian ini adalah penelitian eksperimen. Penelitian ini menggunakan rancangan The Post Test Only Control Group Design. sampel pada penelitian ini berjumlah 55 siswa dari kelas eksperimen 25 siswa dan kelas kontrol 30 siswa yang diambil dengan sistem undian. Instrument yang digunakan yaitu kuisioner dan tes uraian. Data yang diperoleh dianalisis dengan menggunakan statistic deskriptif dan inferensial yaitu uji manova. Hasil penelitian menunjukkan 1) terdapat perbedaan secara simultan sikap sosial dan kemampuan berpikir kritis matematika antara kelompok siswa yang mengikuti model PBL bermuatan kearifan lokal dan kelompok siswa yang mengikuti model pembelajaran konvensional yang dibuktikan dengan nilai signifikansi sebesar $0,000<$ 0,05. 2) terdapat perbedaan sikap sosial antara kelompok siswa yang mengikuti model PBL bermuatan kearifan lokal dan antara kelompok siswa yang mengikuti model pembelajaran konvensional yang dibuktikan dengan nilai signifikansi sebesar $0,000<0,05.3)$ terdapat perbedaan kemampuan berpikir kritis matematika antara kelompok siswa yang mengikuti model PBL bermuatan kearifan lokal dan antara kelompok siswa yang mengikuti model pembelajaran konvensional yang dibuktikan dengan nilai signifikansi sebesar $0,000<0,05$.
\end{abstract}

Kata Kunci: PBL bermuatan kearifan lokal, sikap sosial, kemampuan berpikir kritis

\begin{abstract}
This study aims to find out 1) simultaneous differences in social attitudes and critical thinking skills of mathematics between groups of students who follow the PBL model with local wisdom and groups of students who follow conventional learning in class V students in Cluster V Sukasada District. 2) differences in social attitudes between groups of students who follow the $P B L$ model with local wisdom and groups of students who follow conventional learning in class $V$ students in Cluster $V$ Sukasada District. 3) differences in critical thinking skills of mathematics between groups of students who followed the PBL model with local wisdom and groups of students who followed conventional learning in class $V$ students in Cluster $V$ Sukasada District. This type of research is experimental research. This study uses the design of The Post Test Only Control Group Design. the sample in this study amounted to 55 students from the experimental class 25 students and the control class 30 students taken by the lottery system. The instrument used was questionnaire and description test. The data obtained were analyzed using descriptive and inferential statistics, namely the manova test. The results showed 1) there were simultaneous differences in social attitudes and critical thinking skills of mathematics between groups of students who followed the PBL model with local wisdom and groups of students who followed the conventional learning model as evidenced by a significance value of 0,000 <0,05.2) there are differences in social attitudes between groups of students who follow the PBL model with local wisdom and between groups of students who follow the conventional learning model as evidenced by the significance value of $0,000<0,05.3)$ there are differences in mathematics critical thinking skills between groups of students who follow the PBL model with local wisdom and between groups of students who follow the conventional learning model as evidenced by the significance value of $0,000<0,05$.
\end{abstract}

Keywords: PBL contains local wisdom, social attitudes, critical thinking skills 


\section{Pendahuluan}

Perubahan merupakan sesuatu yang tidak bisa dihindari dalam setiap bidang kehidupan, termasuk bidang pendidikan. Perubahan yang terjadi dalam bidang pendidikan adalah pergantian kurikulum, dari Kurikulum 2006 menjadi Kurikulum 2013. Dalam rangka menerapkan pendidikan yang bermutu, pemerintah telah menetapkan Kurikulum 2013 ini. Hal yang paling menonjol adalah pendekatan dan strategi pembelajarannya. Hal ini membawa konsekuensi perlunya ada perubahan mindset dari metodologi pembelajaran pola lama menuju pada metodologi pembelajaran pola baru sesuai dengan yang diterapkan pada Kurikulum 2013. Guru yang baik adalah guru yang mau menerima perubahan, melakukan pertumbuhan, dan perkembangan dalam dunia pendidikan (Hosnan, 2014:32). Salah satunya melaksanakan pembelajaran sesuai dengan karakteristik abad 21.

Menurut Hosnan (2014:85) dalam pembelajaran abad 21, strategi pembelajaran yang diimplementasikan guru di dalam kelas hendaknya mempunyai beberapa karakteristik, antara lain, (1) pembelajaran berpusat pada peserta didik (student centered), (2) mengembangkan kreativitas peserta didik, (3) menciptakan suasana yang menarik, menyenangkan dan bermakna, (4) mengembangkan kemampuan yang bermuatan nilai dan makna, (5) belajar melalui berbuat (peserta didik aktif berbuat), (6) menekankan pada penggalian, penemuan, dan penciptaan serta (7) menciptakan pembelajaran dalam situasi nyata dan konteks sebenanya. Pembelajaran yang dilaksanakan sesuai dengan karakteristik abad 21, dapat membekali peserta didik dengan keterampilan yang memadai.

Keterampilan yang dibutuhkan oleh peserta didik pada abad 21 adalah Communication, Collaboration, Critical thinking and problem solving, dan Creativity and Innovation. Keempat keterampilan tersebut dapat diuraikan sebagai berikut: 1) Critical thinking and problem sloving. Peserta didik berusaha untuk memberikan penalaran yang masuk akal dalam memahami dan membuat pilihan yang rumit, memahami interkoneksi antara sistem. Peserta didik juga menggunakan kemampuan yang dimilikinya untuk berusaha menyelesaikan permasalahan yang dihadapinya dengan mandiri. 2) Creativity and Innovation. Peserta didik memiliki kemampuan untuk mengembangkan, melaksanakan, dan menyampaikan gagasangagasan baru kepada yang lain, bersikap terbuka dan responsif terhadap perspektif baru dan berbeda. 3) Communication. Pada karakter ini, peserta didik dituntut untuk memahami, mengelola, dan menciptakan komunikasi yang efektif dalam berbagai bentuk dan isi secara lisan, tulisan, dan multimedia. Peserta didik diberikan kesempatan menggunakan kemampuan untuk mengutarakan ide-idenya, baik itu pada saat berdiskusi dengan teman-temannya maupun ketika menyelesaikan masalah dari pendidiknya. 4) Collaboration. Peserta didik menunjukkan kemampuannya dalam kerjasama berkelompok dan kepemimpinan, beradaptasi dalam berbagai peran dan tanggungjawab, bekerja secara produktif dengan yang lain, menempatkan empati pada tempatnya, menghormati perspektif berbeda.

Dari keempat keterampilan abad 21 tersebut salah satunya yaitu, kemampuan berpikir kritis sangat berkaitan dengan pembelajaran matematika. Menurut Susanto (2013:183), matematika merupakan mata pelajaran yang ada pada semua jenjang pendidikan, matematika juga dijadikan sebagai salah satu mata pelajaran penentu kelulusan siswa. Belajar matematika merupakan suatu syarat cukup untuk melanjutkan pendidikan ke jenjang berikutnya. Melalui pembelajaran matematika, seseorang dilatih bernalar secara kritis, kreatif, dan aktif. Pembelajaran matematika sayoganya dapat membangkitkan kemampuan berpikir kritis tersebut.

Namun, pada kenyataannya pembelajaran matematika di sekolah dasar belum mengembangkan kemampuan berpikir kritis siswa. Hal ini terbukti dari hasil UAS siswa masih rendah, seperti yang disajikan pada Tabel 01.

Tabel 01

Nilai rata-rata UAS dan KKM Mata Pelajaran Matematika Siswa Kelas V

\begin{tabular}{|c|c|c|c|c|c|}
\hline No & Nama Sekolah & $\begin{array}{c}\text { Jumlah } \\
\text { Siswa }\end{array}$ & $\begin{array}{c}\text { Kriteria Ketuntasan } \\
\text { Minimal (KKM) }\end{array}$ & $\begin{array}{c}\text { Rata-rata Nilai } \\
\text { UAS }\end{array}$ & $\begin{array}{c}\text { Persentase Siswa di bawah } \\
\text { KKM }\end{array}$ \\
\hline 1 & SDN 1 Panji & 30 & 65 & 68,50 & $26,66 \%$ \\
\hline 2 & SDN 2 Panji & 29 & 65 & 65,69 & $34,48 \%$ \\
\hline 3 & SDN 3 Panji & 24 & 65 & 65,46 & $33,33 \%$ \\
\hline 4 & SDN 4 Panji & 25 & 65 & 69,16 & $20,00 \%$ \\
\hline 5 & SDN 5 Panji & 28 & 65 & 65,04 & $30,76 \%$ \\
\hline 6 & SDN 6 Panji & 13 & 65 & 65,54 & $20,68 \%$ \\
\hline 7 & SDN 1 Sambangan & 29 & 61 & 66,72 & $38,09 \%$ \\
\hline 8 & SDN 2 Sambangan & 21 & 75 & 74,52 & $33,33 \%$ \\
\hline 9 & SDN 3 Sambangan & 33 & 75 & 73,79 & \\
\hline
\end{tabular}

(Dokumentasi hasil UAS Matematika Kelas 5 SD, 2018)

Berdasarkan data yang diperoleh pada Tabel 1 di atas, dapat dikatakan bahwa rata-rata UAS mata pelajaran matematika di Gugus V Kecamatan Sukasada rendah. Hal ini terbukti masih banyak siswa yang belum mencapai KKM. Rendahnya rata-rata nilai UAS, mencerminkan kemampuan berpikir kristis belum optimal. Belum optimalnya kemampuan berpikir kritis matematika menunjukkan bahwa kualitas pembelajaran matematika di Gugus V Kecamatan Sukasada masih perlu ditingkatkan. Belum optimalnya kualitas pembelajaran matematika di Gugus V Kecamatan Sukasada, karena pembelajaran matematika didominasi oleh pembelajaran konvensional dengan metode ceramah. Hal tersebut juga dibuktikan dengan adanya sekolah yang memiliki rata-rata di bawah Kriteria Ketuntasan Minimal (KKM). Walaupun rata-rata nilai UAS matematika sudah sebagian sekolah di atas Kriteria Ketuntasan Minimal (KKM), namun nilai tersebut masih tergolong rendah dan tidak menunjukkan hasil maksimal, karena rata-rata nilai UAS matematika masih pada kisaran Kriteria Ketuntasan Minimal (KKM) sekolah. Dengan belum optimalnya kualitas pembelajaran matematika di Gugus V Kecamatan Sukasada, maka guru dapat menggunakan model Problem Based Learning (PBL) Bermuatan Kearifan Lokal. 
Selain kemampuan berpikir kritis, sikap sosial siswa belum mendapatkan perhatian. Hal ini terbukti dari hasil wawancara pada hari jumat, 4 Januari 2019 dengan wali kelas V SD di Gugus V Kecamatan Sukasada, yaitu (1) kendala yang dialami guru terletak pada siswa yaitu siswa kurang aktif baik bertanya maupun menjawab saat pembelajaran berlangsung, (2) kebanyakan siswa yang masih sulit dalam menerima materi-materi pelajaran, (3) masih ada beberapa siswa yang sikapnya masih kurang baik dalam mengikuti pembelajaran, (4) masih ada beberapa siswa yang kurang ikut bekerjasama saat mengerjakan tugas kelompok, dan (5) kurang adanya interaksi antara siswa dengan siswa, guru dengan siswa.

Berdasarkan permasalahan di atas, perlu diupayakan solusi alternatif berkaitan dengan pembelajaran inovatif. Salah satu model pembelajaran inovatif adalah model pembelajaran Problem Based Learning (PBL) bermuatan kearifan lokal. Menurut Dunch (dalam Shoimin, 2013), Problem Based Learning (PBL) adalah model pengajaran yang bercirikan adanya permasalahan nyata sebagai konteks untuk para peserta didik belajar berpikir kritis dan keterampilan memecahkan masalah serta memperoleh pengetahuan. Dengan adanya model Problem Based Learning (PBL) bermuatan kearifan lokal ini diharapkan dapat memengaruhi sikap sosial dan proses pembelajaran menjadi menyenangkan dan kondusif, serta kemampuan berpikir kritis matematika siswa yang diharapkan dapat tercapai dengan baik.

\section{Metode}

Rancangan penelitian yang digunakan adalah non equivalent post-test only control group design. Populasi dalam penelitian ini adalah semua siswa kelas V SD di Gugus V Kecamatan Sukasada sebanyak 232 orang. Sebaran populasi dapat dilihat pada Tabel 02

Tabel 02

Distribusi Sumber Populasi

\begin{tabular}{|c|c|c|}
\hline No & Nama Sekolah Dasar & Jumlah Siswa \\
\hline 1 & SDN 1 Panji & 30 \\
\hline 2 & SDN 2 Panji & 29 \\
\hline 3 & SDN 3 Panji & 24 \\
\hline 4 & SDN 4 Panji & 25 \\
\hline 5 & SDN 5 Panji & 28 \\
\hline 6 & SDN 6 Panji & 13 \\
\hline 7 & SDN 1 Sambangan & 29 \\
\hline 8 & SDN 2 Sambangan & 21 \\
\hline 9 & SDN 3 Sambangan & 33 \\
\hline & Total Jumlah Siswa & 232 \\
\hline
\end{tabular}

Dalam penelitian ini, sampel ditentukan dengan menggunakan group random sampling. Sebelum menetapkan sampel penelitian terlebih dahulu dilakuan uji kesetaraan pada masing-masing kelas. Hasil uji kesetaraan diperoleh hasil bahwa seluruh kelas V SD di Gugus V Kecamatan Sukasada memiliki kemampuan yang setara. Untuk menentukan kelas eksperimen dan control, peneliti melakukan system undian. Hasil undian tersebut V di SDN 4 Panji dipilih sebagai kelas eksperimen dan SDN 1 Panji sebagai kelas control.

Data pada penelitian ini dikumpulkan dengan beberapa metode pengumpulan data yang disesuaikan dengan permasalahan yang dikaji pada penelitian ini. Sesuai dengan permasalahannya maka data yang diperlukan, yaitu sikap sosial dan kemampuan berpikir kritis Matematika. penelitian ini data kemampuan berpikir kritis Matematika diperoleh melalui tes objektif dan sikap sosial melalui pemberian kuisioner.

Hasil penelitian ini dianalisis bertahap yaitu: analisis deskriptif dan inferensial. Uji prasyarat yang dilakukan adalah uji normalitas sebaran data, uji homogenitas varians, dan uji korelasi antar variable terikat. Uji normalitas dilakukan untuk meyakinkan bahwa sampel berasar dari populasi yang berdistribusi normal, sehingga uji hipotesis dapat dilakukan. Uji normalitas data dilakukan pada empat kelompok data yaitu: 1) data sikap sosial kelompok eksperimen, 2) data sikap sosial kelompok kontrol, 3) kemampuan berpikir kritis matematika eksperimen dan 4) kemampuan berpikir kritis matematika kelompok control.

Uji homogenitas dimagsud untuk memperlihatkan bahwa dua atau lebih kelompok data sampel berasal dari populasi yang memiliki varian yang sama, sedangkan uji kolerasi antara variabel terikat dlakukan untuk mengetahui apakah apakah kolerasi antar variabek terikat tersebut tinggi atau rendah. Karena, jika antar variabel terikat tinggi maka variable terikat tidak dapat dipisahkan, sedangkan jika kolerasi antar variable terikat rendah atau tidak ada kolerasi variable terikat dalam penelitian ini dapat dipisahkan. Data dianalisis menggunakan uji dengan bantuan SPSS 17.00 for windows pada taraf signifikasi $5 \%$.

\section{Hasil dan Pembahasan}

Hasil penelitian secara deskriptif memaparkan tentang hasil perhitungan mean, standar deviasi, range, skor/nilai maksimum, skor/nilai, minimum. Berdasarkan analisis deskriptif yang dilakukan terdapat empat skor/nilai menunjukan bahwa secara deskriptif kelompok siswa yang belajar menggunakan model pembelajaran Problem Based Learning (PBL) bermuatan kearifan lokal tinggi dibandingkan kelompok siswa yang dibelajarakan dengan model pembelajaran konvensional.

Berdasarkan analisis data deskriptif, tampak bahwa sikap sosial dan keterampilan berpikir kritis Matematika siswa yang menggunakan model pembelajaran Problem Based Learning (PBL) bermuatan kearifan lokal lebih baik daripada model pembelajaran konvensional. Hal ini ditunjukan oleh rata-rata nilai sikap sosial siswa yang belajar menggunakan model pembelajaran Problem Based Learning (PBL) bermuatan kearifan lokal adalah 103,00, sedangkan rata-rata nilai sikap sosial 
siswa yang menggunakan model pembelajaran konvensional adalah 84,13 . Nilai rata-rata kemampuan berpikir keritis Matematika siswa yang belajar menggunakan model pembelajaran Problem Based Learning (PBL) bermuatan kearifan lokal adalah 19,95, sedangkan rata-rata siswa yang menggunakan model pembelajaran konvesional 14,00. Dapat diimpulkan bahwa sikap sosial dan kemampuan berpikir keritis Matematika siswa yang menggunakan model pembelajaran Problem Based Learning (PBL) bermuatan kearifan lokal lebih baik daripada siswa yang menggunakan model pembelajaran konvensional.

Untuk menguji normalitas sebaran data, digunakan SPSS-07 for windows. Berdasarkan hasil analisis menggunakan SPSS-07 for windows dengan uji statistic Kolmogorov-Smirnov pada taraf signifikansi 0,05, maka didapatkan hasil seperti Tabel 03.

Tabel 03

Hasil uji normalitas Sebaran data dengan teknik Kolmogrov-Smirnov dan

Shapiro-Wilk dengan Taraf Signifikansi 5\%.

\begin{tabular}{|l|l|r|r|r|r|r|r|}
\hline & Kelompok & \multicolumn{2}{|c|}{ Kolmogorov-Smirnov $^{\mathrm{a}}$} & \multicolumn{3}{|c|}{ Shapiro-Wilk } \\
\hline & & Statistic & Df & \multicolumn{1}{c|}{ Sig. } & \multicolumn{1}{c|}{ Statistic } & \multicolumn{1}{c|}{ df } & \multicolumn{1}{c|}{ Sig. } \\
\hline \multirow{2}{*}{ Sikap Sosial } & Eksperimen & .119 & 25 & $.200^{*}$ & .955 & 25 & .328 \\
\cline { 2 - 8 } & Kontrol & .130 & 30 & $.200^{*}$ & .946 & 30 & .133 \\
\hline Kemampuan Berpikir Kritis & Eksperimen & .135 & 25 & $.200^{*}$ & .942 & 25 & .169 \\
\cline { 2 - 8 } & Kontrol & .131 & 30 & $.200^{*}$ & .954 & 30 & .212 \\
\hline
\end{tabular}

Berdasarkan Tabel 03 terlihat bahwa semua variable angkat statistic Kolmogrov Smirnov lebih besar dari 0,05. Hal ini menunjukan bahwa semua sebaran data berdistribusi normal. Setelah diketahui bahwa seluruh sebaran data berdistribusi normal, maka dilanjutkan dengan uji homogenitas varian. Unutuk menguji homogenitas varian, digunakan SPSS-17,00 for windows. Berdasarkan hasil analisis didapatkan hasil seperti Tabel 04.

Tabel 04

Hasil analisis uji test of homogeneity of variance

\begin{tabular}{|c|c|c|c|c|c|}
\hline & & $\begin{array}{l}\text { Levene } \\
\text { Statistic }\end{array}$ & df1 & df2 & Sig. \\
\hline \multirow[t]{4}{*}{ Sikap Sosial } & Based on Mean & .074 & 1 & 53 & .787 \\
\hline & Based on Median & .080 & 1 & 53 & .778 \\
\hline & $\mid \begin{array}{l}\text { Based on Median and with } \\
\text { adjusted df }\end{array}$ & .080 & 1 & 52.999 & .778 \\
\hline & Based on trimmed mean & .072 & 1 & 53 & .789 \\
\hline \multirow{4}{*}{$\begin{array}{l}\text { Kemampuan } \\
\text { Berpikir Kritis }\end{array}$} & Based on Mean & .001 & 1 & 53 & .982 \\
\hline & Based on Median & .019 & 1 & 53 & .892 \\
\hline & $\begin{array}{l}\text { Based on Median and with } \\
\text { adjusted df }\end{array}$ & .019 & 1 & 52.976 & .892 \\
\hline & Based on trimmed mean & .007 & 1 & 53 & .935 \\
\hline
\end{tabular}

Berdasarkan Tabel 04 menunjukan bahwa angka signifikan yang dihasilkan baik secara Bersama maupun sendiri lebih besar dari 0,05. Dengan demikian variable sikap sosial dan kemampuan berpikir kritis Matematika adalah homogen. Setelah uji normalitas dan homogenitas dilanjutkan dengan uji korelasi variabel terikat dengan menggunkan rumus product moment berikut disajikan pada Tabel 05 .

Tabel 05

Tabel Hasil Korelasi Antar Variabel

\begin{tabular}{|l|l|r|r|}
\hline & & Sikap Sosial & \multicolumn{1}{c|}{$\begin{array}{c}\text { Kemampuan } \\
\text { Berpikir Kritis }\end{array}$} \\
\hline Sikap Sosial & Pearson Correlation & 1 & .001 \\
& Sig. (2-tailed) & 55 & $.783 * *$ \\
& N & .001 & 55 \\
\hline Kemampuan Berpikir Kritis & Pearson Correlation & $.783 * *$ & 1 \\
& Sig. (2-tailed) & 55 & 55 \\
\cline { 2 - 4 } & N & & \\
\end{tabular}


Berdasarkan Tabel 05 menunjukkan bahwa angka signifikan yang dihasilkan secara terpisah lebih besar dari 0,05. Dengan demikian dapat disimpulkan bahwa variabel sikap sosial dan kemampuan berpikir kritis adalah homogen dan data dapat dilanjutkan dengan uji manova.

Pertama, hasil analisis menunjukan bahwa nilai signifikan Pillai's Treace, Wilks'Lambda, Hotelling's Trice, dan Roy's Larget Root sebesar 0.000 dan lebih kecil dari 0,05. Sehingga dapat disimpulkan bahwa hipotesis nol (H0) ditolak dan hipotesis alternative (Ha) diterima. Jadi terdapat perbedaan yang signifikan sikap sosial dan kemampuan berpikir kritis matematika siswa yang mengikuti model Problem Based Learning (PBL) bermuatan kearifan lokal dan siswa yang mengikuti pembelajaran konvensional. Hasil analisis disajikan pada Tabel 06.

Tabel 06

Multivariate Test

\begin{tabular}{|ll|r|r|r|r|r|}
\hline Effect & & Value & \multicolumn{1}{c|}{$\mathrm{F}$} & Hypothesis df & Error df & \multicolumn{1}{c|}{ Sig. } \\
\hline Intercept & Pillai's Trace & .996 & $5861.123^{\mathrm{a}}$ & 2.000 & 52.000 & .000 \\
& Wilks' Lambda & .004 & $5861.123^{\mathrm{a}}$ & 2.000 & 52.000 & .000 \\
& Hotelling's Trace & 225.428 & $5861.123^{\mathrm{a}}$ & 2.000 & 52.000 & .000 \\
& Roy's Largest Root & 225.428 & $5861.123^{\mathrm{a}}$ & 2.000 & 52.000 & .000 \\
\hline Y & .703 & $61.644^{\mathrm{a}}$ & 2.000 & 52.000 & .000 \\
& Pillai's Trace & .297 & $61.644^{\mathrm{a}}$ & 2.000 & 52.000 & .000 \\
& Wilks' Lambda & 2.371 & $61.644^{\mathrm{a}}$ & 2.000 & 52.000 & .000 \\
& Hotelling's Trace & 2.371 & $61.644^{\mathrm{a}}$ & 2.000 & 52.000 & .000 \\
\hline
\end{tabular}

kedua, hasil analisis menunjukan bahwa nilai signifikan sikap sosial pada kolom kelompok (Y) sebesar 0.000 dan lebih kecil dari 0.05. sehingga dapat disimpulkan bahwa hipotesis nol (H0) ditolak dan hipotesis alternative (Ha) diterima. Hal ini berarti bahwa terdapat perbedaan yang signifikan sikap sosial antara siswa yang mengikuti model Problem Based Learning (PBL) bermuatan kearifan lokal dan siswa yang mengikuti pembelajaran konvensional. Adapun ringkasan analisis data hipotesis 2 dan 3 dapat dilihat pada Tabel 07.

Tabel 07

Test Of Between-Subject Effects

\begin{tabular}{|c|c|c|c|c|c|c|}
\hline Source & $\begin{array}{l}\text { Dependent } \\
\text { Variable }\end{array}$ & $\begin{array}{l}\text { Type III Sum of } \\
\text { Squares }\end{array}$ & $\mathrm{df}$ & Mean Square & $\mathrm{F}$ & Sig. \\
\hline \multirow[t]{2}{*}{ Corrected Model } & Sikap Sosial & $4853.879^{\mathrm{a}}$ & 1 & 4853.879 & 111.007 & .000 \\
\hline & $\begin{array}{l}\text { Kemampuan } \\
\text { Berpikir Kritis }\end{array}$ & $188.705^{\mathrm{b}}$ & 1 & 188.705 & 18.084 & .000 \\
\hline \multirow[t]{2}{*}{ Intercept } & Sikap Sosial & 477530.242 & 1 & 477530.242 & 10921.021 & .000 \\
\hline & $\begin{array}{l}\text { Kemampuan } \\
\text { Berpikir Kritis }\end{array}$ & 13720.342 & 1 & 13720.342 & 1314.874 & .000 \\
\hline \multirow[t]{2}{*}{$\mathrm{Y}$} & Sikap Sosial & 4853.879 & 1 & 4853.879 & 111.007 & .000 \\
\hline & $\begin{array}{l}\text { Kemampuan } \\
\text { Berpikir Kritis }\end{array}$ & 188.705 & 1 & 188.705 & 18.084 & .000 \\
\hline \multirow[t]{2}{*}{ Error } & Sikap Sosial & 2317.467 & 53 & 43.726 & & \\
\hline & $\begin{array}{l}\text { Kemampuan } \\
\text { Berpikir Kritis }\end{array}$ & 553.040 & 53 & 10.435 & & \\
\hline \multirow[t]{2}{*}{ Total } & Sikap Sosial & 479895.000 & 55 & & & \\
\hline & $\begin{array}{l}\text { Kemampuan } \\
\text { Berpikir Kritis }\end{array}$ & 14283.000 & 55 & & & \\
\hline \multirow[t]{2}{*}{ Corrected Total } & Sikap Sosial & 7171.345 & 54 & & & \\
\hline & $\begin{array}{l}\text { Kemampuan } \\
\text { Berpikir Kritis }\end{array}$ & 741.745 & 54 & & & \\
\hline
\end{tabular}

Ketiga, hasil analisis menunjukan bahwa nilai signifikan kemampuan berpikir kritis matematika pada kolom model sebesar 0.025 dan lebih kecil dari 0.05. sehingga dapat disimpulkan bahwa hipotesis nol (H0) ditolak dan hipotesis alternative (Ha) diterima. Hal ini berarti bahwa terdapat perbedaan yang signifikan kemampuan berpikir kritis matematika antara siswa yang mengikuti model pembelajaran Problem Based Learning (PBL) bermuatan kearifan lokal dan siswa yang mengikuti pembelajaran konvensional.

Temuan pertama dalam penelitian ini adalah terdapat perbedaan sikap sosial dan kemampuan berpikir kritis matematika antara kelompok siswa yang mengikuti model PBL bermuatan kearifan lokal dengan kelompok siswa yang 
mengikuti model pembelajaran konvensional siswa kelas V di Gugus V Kecamatan Sukasada. Hal ini dapat dilihat dari nilai $\mathrm{F}=61,644$ hitung untuk Pillae Trace, Wilk Lambda, Hotteling's Trace, Roy's Largest Root nilai dengan signifikansi $0,000<$ 0,05. Artinya semua nilai Pillae Trace, Wilk Lambda, Hotteling's Trace, Roy's Largest Root signifikan. Hal ini berarti model PBL bermuatan kearifan lokal berpengaruh positif terhadap sikap sosial dan kemampuan berpikir kritis matematika menunjukkan sikap sosial dan kemampuan berpikir kritis matematika lebih baik daripada model pembelajaran konvensional.

Secara teoretis model PBL adalah teknik pembelajaran untuk membantu siswa dalam memecahkan suatu masalah. Menurut Finkle Trop (1995), model Problem Based Learning (PBL) merupakan pengembangan kurikulum dan sistem pengajaran yang mengembangkan secara silmultan strategi pemecahan masalah dan dasar-dasar pengetahuan dan keterampilan dengan menempatkan peserta didik dalam peran aktif sebagai pemecahan masalah sehari-hari yang tidak terstruktur dengan baik. Sedangkan kearifan lokal bagian dari kebudayaan yang sudah menstradisi sesuai dengan agamamnya masing-masing.

Hasil penelitian ini sejalan dengan hasil penelitian dari 1) Khori, dkk (2013) yang berjudul "Problem Based Learning Berbantuan Multimedia Dalam Pembelajaran Matematika Untuk Meningkatkan Kemampuan Berpikir Kreatif." 2) Anggreni, dkk (2013) yang berjudul "Implementasi Strategi Pembelajaran Inkuiri Terhadap Kemampuan Berpikir Kritis Dan Pemahaman Konsep IPA." 3) Supriadi (2013) dengan penelitiannya yang berjudul "Pengaruh Penerapan Model Problem Based Learning (PBL) Berbantuan Audiovisual Terhadap Hasil Belajar IPS Siswa Kelas IV SD Gugus Ubud Gianyar Tahun Pelajaran 2012/2013" menghasilkan penelitian yang menunjukkan bahwa adanya peningkatan hasil belajar siswa dalam mata pelajaran IPA melalui model pembelajaran PBL. 4) Astawan, dkk (2018) yang berjudul "ilmu pengetahuan alam bermuatan kearifan lokal untuk siswa kelas IV SD. 5) Ari Yudani, dkk (2016) yang berjudul "penerapan model problem based learning berbantuan media questions BOX untuk meningkatkan hasil belajar IPA siswa.

Temuan kedua penelitian ini adalah terdapat perbedaan sikap sosial antara kelompok siswa yang mengikuti model Problem Based Learning (PBL) bermuatan kearifan lokal dengan kelompok siswa yang mengikuti pembelajaran konvensional pada siswa kelas V SD di Gugus V Kecamatan Sukasada. Dapat dilihat dari nilai koefesien F= 111,007 dengan signifikansi (sig) $=<0,05$. Jika ditetapkan taraf signifikansi $\alpha=0,05$ maka nilai signifikansi uji hipotesis kedua jauh lebih kecil daripada $\alpha$, sehingga $\mathrm{F}$ signifikan maka hipotesis kedua diterima. Hasil analisis ini juga dibuktikan secara langsung melalui pengamatan ketika proses pembelajaran berlangsung. Pada kelas eksperimen yang diberikan perlakuan berupa model PBL bermuatan kearifan lokal dalam mata pelajaran matematika membuat siswa lebih bersemangat memiliki rasa percaya diri, membiasakan siswa untuk menggali informasi dan menentukan konsep dengan sendirinya. Sementara pada kelas kontrol yang menggunakan pembelajaran konvensional siswa terlihat pasif dan siswa hanya menunggu penjelasan dari guru tanpa mau mencari sendiri tentang materi yang sedang diajarkan.

Untuk mendapatkan hasil yang maksimal, guru dapat menggunakan pembelajaran dengan model PBL bermuatan kearifan lokal juga dapat menimbulkan sikap sosial siswa. Dalam proses pembelajaran, siswa lebih terlihat aktif dalam melaksanakan tugas belajarnya, lebih berani bertanya, bekerjasama dalam kelompok. Timbulnya sikap sosial dapat meningkatkan pemahamannya terhadap materi yang sedang dipelajarinya. Sikap sosial penting dimiliki siswa mengingat bangsa kita adalah bangsa yang terdiri dari beberapa suku, agama, adat istiadat yang sering kita kenal dengan sebutan Bhineka Tunggal Ika, menurut Wartini, dkk. (2014) sehingga ketika mereka berinteraksi baik dengan sesama teman ataupun dengan guru bisa saling menghargai dalam segi perbedaan pendapat atau dari segi kemajemukan yang terdapat di dalam kelas. Menurut Cakra dkk. (2015) sikap sosial adalah kesadaran dari dalam diri individu yang mempengaruhi terhadap lingkungan sosial. Sikap sosial adalah kesadaran individu yang berulang-ulang terhadap objek sosial. Sejalan dengan pengertian sikap yang dijelaskan sebelumnya, maka dapat dipahami bahwa sikap sosial adalah sikap yang ditumbuhkan dan dipelajari sepanjang perkembangan orang yang bersangkutan dalam keterkaitannya dengan objek tertentu.

Hasil penelitian ini sejalan dengan penelitian yang dilakukan oleh 1) Vivin (2013) yang berjudul "peningkatan aktivitas dan hasil belajar siswa melalui model Problem Based Learning (PBL)" 2) sejalan juga dengan hasil penelitian dari Sri Wahyuni (2014) yang berjudul "Mengembangkan keterampilan berpikir kritis siswa melalui pembelajaran IPA bebasis Problem Based Learning. 3) Siswantara (2013) dengan penelitiannya yang berjudul “ Penerapan Model Problem Based Learning Untuk Meningkatkan Aktivitas dan Hasil Belajar IPA Siswa Kelas IV SD Negeri 8 Kesiman Tahun Pelajaran 2012/2013" menghasilkan penelitian yang menunjukkan bahwa adanya peningkatan hasil belajar siswa dalam mata pelajaran IPA melalui model pembelajaran PBL. 4) Rusmin Tumanggor (2015) yang berjudul pemberdayaan kearifan lokal memacu kesetaraan komunitas adat terpencil.

Temuan ketiga penelitian ini adalah terdapat perbedaan kemampuan berpikir kritis matematika antara kelompok siswa yang mengikuti model Problem Based Learning (PBL) bermuatan kearifan lokal dengan kelompok siswa yang mengikuti pembelajaran konvensional pada siswa kelas V SD di Gugus V Kecamatan Sukasada. Dapat dilihat dari nilai koefesien $\mathrm{F}=18,084$ dengan signifikansi (sig) $=<0,05$. Jika ditetapkan taraf signifikansi $\alpha=0,05$ maka nilai signifikansi uji hipotesis kedua jauh lebih kecil daripada $\alpha$, sehingga $F$ signifikan maka hipotesis kedua diterima. Hasil analisis ini juga dibuktikan secara langsung melalui pengamatan ketika proses pembelajaran berlangsung. Proses pembelajaran di kelas eksperimen menggunakan model PBL bermuatan kearifan lokal, dengan menggunakan model tersebut siswa akan lebih aktif dan tidak merasa bosan selama mengikuti proses pembelajaran. Kemampuan seseorang dalam berpikir kritis dapat dikenali dari tingkah laku yang diperlihatkannya selama proses berpikir. Hasil penelitian ini sejalan dengan penelitian yang dilakukan oleh 1) Lia Vendiagrys, dkk (2015) yang berjudul "analisis kemampuan pemecahan masalah matematika soal setipe timss berdasarkan gaya kognitif siswa pada pembelajaran Problem Based Learning (PBL)" 2) Dinasti (2012) dengan penelitiannya yang berjudul "Penerapan Model Pembelajaran Problem Based Learning Berbantuan Media Video Pembelajaran Untuk Meningkatkan Hasil Belajar IPS Siswa Kelas V Semester II SD NO. 4 Kampung Baru Singaraja Tahun Pelajaran 2011/2012" menghasilkan penelitian yang menunjukkan bahwa adanya peningkatan hasil belajar siswa dalam mata pelajaran IPS melalui model pembelajaran PBL. Hal ini terbukti dengan peningkatan persentase rata-rata hasil belajar mencapai 85,52\%. 3) Gunantara, dkk (2014) yang berjudul "penerapan model problem based learning untuk meningkatkan kemampuan pemecahan masalah matematika siswa v. 4) Fitriyani, dkk (2015) yang berjudul "pengaruh model SAVI terhadap kemampuan berpikir kritis siswa dalam mata pelajaran IPA kelas V SD. 


\section{Simpulan}

Berdasarkan hasil analisis data dan pembahasan yang telah dipaparkan di atas sebagai berikut: 1) Terdapat perbedaan yang signifikan sikap sosial dan kemampuan berpikir kritis matematika antara kelompok siswa yang mengikuti model Problem Based Learning (PBL) bermuatan kearifan lokal dan kelompok siswa yang mengikuti pembelajaran konvensional siswa kelas V di Gugus V Kecamatan Sukasada Tahun Pelajaran 2018/2019. Model PBL bermuatan kearifan lokal lebih baik dibandingkan model pembelajaran konvensional dalam pencapaian sikap sosial dan kemampuan berpikir kritis siswa. Dengan kata lain, ada pengaruh signifikan model PBL bermuatan kearifan lokal terhadap pencapaian sikap sosial dan kemampuan berpikir kritis siswa. Hal ini dilihatkan dari nilai signifikan Pillai's Treace, Wilks'Lambda, Hotelling's Trice, dan Roy's Larget Root sebesar $0.000<0,05.2$ ) Terdapat perbedaan yang signifikan sikap sosial antara kelompok siswa yang mengikuti model PBL bermuatan kearifan lokal dengan kelompok siswa yang mengikuti model pembelajaran konvensional siswa kelas V di Gugus V Kecamatan Sukasada. Model PBL bermuatan kearifan lokal lebih baik dibandingkan model pembelajaran konvensional dalam pencapaian sikap sosial siswa. Dengan kata lain, ada pengaruh signifikan model PBL bermuatan kearifan lokal terhadap pencapaian sikap sosial siswa. Hal ini dilihatkan dari nilai signifikan uji Test of Between Subject Effect, didapatkan nilai signifikan sikap sosial pada kolom model sebesar $0,000<0,05$. Disamping itu, ditindaklanjuti dengan analisis Pairwise Comparisons dengan nilai Mean Difference (I-J) sebesar 18.867 (bernilai positif), signifikansi sebesar $0,000<0,05$. Hal ini berarti, terdapat pengaruh yang signifikan model PBL bermuatan kearifan lokal terhadap sikap sosial siswa kelas V di Gugus V Kecamatan Sukasada. 3) Terdapat perbedaan yang signifikan kemampuan berpikir kritis matematika antara siswa yang mengikuti model pembelajaran Problem Based Learning (PBL) bermuatan kearifan lokal dan siswa yang mengikuti pembelajaran konvensional siswa kelas V di Gugus V Kecamatan Sukasada Tahun Pelajaran 2018/2019. Model PBL bermuatan kearifan lokal lebih baik dibandingkan model pembelajaran konvensional dalam pencapaian kemampuan berpikir kritis siswa. Dengan kata lain, ada pengaruh signifikan model PBL bermuatan kearifan lokal terhadap pencapaian kemampuan berpikir kritis siswa. Hal ini dilihatkan dari nilai signifikan uji Test of Between Subject Effect di atas, didapatkan nilai signifikan kemampuan berpikir kritis matematika pada kolom model sebesar 0.000 dan lebih kecil dari 0.05. Di samping itu, ditindaklanjuti dengan analisis Pairwise Comparisons dengan nilai Mean Difference (I-J) sebesar 3.720 (bernilai positif), signifikansi sebesar $0,000<0,05$. Hal ini berarti, terdapat pengaruh yang signifikan model PBL bermuatan kearifan lokal terhadap kemampuan berpikir kritis matematika siswa kelas V di Gugus V Kecamatan Sukasada.

Berdasarkan temuan penelitian, disarankan 1) kepada guru agar menerapkan model PBL bermuatan kearifan lokal, karena hasil penelitian yang sudah dilakukan membuktikan bahwa penggunaan model PBL bermuatan kearifan lokal mampu meningkatkan sikap sosial dan kemampuan berpikir kritis matematika siswa. 2) kepada sekolah agar dapat menggunakan hasil penelitian ini sebagai acuan pedoman untuk membimbing guru-guru dalam melaksanakan proses pembelajaran dengan menggunaka model PBL bermuatan kearifan lokal untuk meningkatkan sikap sosial dan kemampuan berpikir kritis matematika siswa.

\section{Daftar Pustaka}

Agustin, V. N. 2013. "Peningkatan Aktivitas dan Hasil Belajar Siswa Melalui Model Problem Based Learning (PBL)." Semarang: Universitas Negeri Semarang.

Anggreni. N.W., Ristiati. N. P., Widyanti. N. L. P. M. 2013. "Implementasi Strategi Pembelajaran Inkuiri Terhadap Kemampuan Berpikir Kritis Dan Pemahaman Konsep IPA.” Singaraja: Universitas Pendidikan Ganesha.

Ari Yudani, N.Km. 2016. "Penerapan Model Pembelajaran PBL Berbantuan Media Questions Box Untuk Meningkatkan Hasil Belajar IPA Siswa." Singaraja: Universitas Pendidikan Ganesha.

Astawan,I.G., Suryadarma. I.G.P., Sujarwo. 2018. "Ilmu Pengetahuan Alam Bermuatan Kearifan Lokal Untuk Siswa Kelas IV SD."

Dinasti, K. 2012. "Penerapan Model Pembelajaran Problem Based Learning (PBL) Berbantuan Media Video Pembelajaran untuk Meningkatkan Hasil Belajar IPS Siswa Kelas V Semester II SD NO 4 Kampung Baru Singaraja Tahun Pelajaran 2011/2012”. Skripsi (Tidak diterbitkan): Universitas Pendidikan Ganesha.

Fitriyani, I.Gn., Suwatra., I.,Wy., Kusmariyatni., Nym. 2015. "Pengaruh Model Savi Terhadap Kemampuan Berpikir Kritis Siswa Dalam Mata Pelajaran IPA Kelas V SD.” Singaraja: Universitas Pendidikan Ganesha.

Gunantara. G., Suarjana. M., Nanci Riastini. 2014. "Penerapan Model Pembelajaran Problem Based Learning Untuk Meningkatkan Kemampuan Pemecahan Masalah Matematika Siswa Kelas V." Singaraja: Universitas Pendidikan Ganesha.

Hosnan. 2014. Pendekatan Saintifik dan Kontekstual dalam Pembelajaran Abad 21. Bogor: Ghalia Indonesia.

Khori. W., Rochmad., Adi. N. C. 2013. "Problem Based Learning Berbantuan Multimedia Dalam Pembelajaran Matematika Untuk Meningkatkan Kemampuan Berpikir Kreatif.” Semarang: Kampus Sekaran Gunungpati.

Rusmin, T. 2015.”Pemerdayaan Kearifan Lokal Memacu Kesetaraan Komunitas Adat Terpencil.”

Shoimin, A. 2014. 68 Model Pembelajaran Inovatif dalam Kurikulum 2013. Yogyakarta: A-Ruzz Media.

Siswantara, I Kadek Agus. 2013. "Penerapan Model Pembelajaran Problem Based Learning untuk Meningkatkan Aktivitas dan Hasil BelajarHasil Belajar IPA Siswa Kelas IV SD Negeri 8 Kesiman Tahun Pelajaran 2012/2013”. Skripsi (Tidak diterbitkan): Universitas Pendidikan Ganesha.

Susanto, A. 2013. Teori Belajar dan Pembelajaran di Sekolah Dasar. Jakarta: Kencana Prenada Media Group.

Supriadi, I Made, Kadek. 2013. "Pengaruh Penerapan Model Pembelajaran Problem Based Learning (PBL) Berbantuan Audio Terhadap Hasil Belajar IPS Siswa Kelas IV Gugus Ubud Tahun Pelajaran 2011/2012”. Skripsi (Tidak diterbitkan): Universitas Pendidikan Ganesha.

Vendiagrys. L., Iwan. J., Masrukan. 2015. "Analisis Kemampuan Pemecahan Masalah Matematika Soal Setipe Timss Berdasarkan Gaya Kognitif Siswa Pada Pembelajaran Model Problem Based Learning (PBL)." Semarang: Universitas Negeri Semarang. 